\title{
Evaluation of Soil Fertility of Golpura Village of Dhar District of Western Madhya Pradesh, India
}

\author{
Chandan Bala Lohiya, Shila P.K. Unni* and Sanjay Sharma
}

Department of Soil Science and Agricultural Chemistry, Rajmata Vijayaraje Scindia Krishi Vishwa Vidyalaya, Gwalior, College of Agriculture Indore (M P.), India

*Corresponding author

\section{Keywords \\ Soil fertility, Physico chemical characteristics}

\section{Article Info}

Accepted:

04 March 2018

Available Online:

10 April 2018

\section{A B S T R A C T}

The present investigation was undertaken with a view to evaluate the fertility status of Vertisols and associated soils of Golpura village in Dhar district of Madhya Pradesh and its relationship with important physico chemical characteristics for identifying the location specific conditions promoting nutrient deficiencies and realistic assessment of need for nutrients. The highlights of the investigation are summarized and concluded with following objective: to estimate the major nutrient status (N, P and $\mathrm{K}$ ) and secondary nutrient(S) of the sampled soil, to assess the soil reaction $(\mathrm{pH})$ and electrical conductivity (EC) and organic carbon in different soil samples of the study area, to study the micronutrients ( $\mathrm{Fe}, \mathrm{Zn}, \mathrm{Mn}$ and $\mathrm{Cu}$ ) status in sampled soil, to determine the textural class of sampled soils of the village and to quantify the relationship between organic carbon and available $\mathrm{N}$ content in soil through correlation. It can be concluded from the above results that the Soils of Golpura village in Dhar district of Madhya Pradesh were low in available $\mathrm{N}$, low to medium available $\mathrm{P}$ and $\mathrm{S}$, medium to high level in available $\mathrm{K}$ and characterized under neutral to alkaline in soil reaction $(\mathrm{pH})$ and less than one $\mathrm{d} \mathrm{Sm-1}$ soluble salt content (EC) comes under safe limit for all soils. Out of total soil samples were tested high level DTPA-extractable $\mathrm{Cu}$, medium level Fe whereas, $\mathrm{Zn}$ and Mn deficiency was observed in study area. The organic carbon level exhibited low to medium and positively significant correlation was exhibited amongst OC and available N. Most of the soils of Golpura village were characterized by Low, Medium and High categories. Hence, the soils require attention regarding nutrient management practices and regular monitoring of soil health for better crop production, in future. From the study, it can be concluded that, soils of Golpura village in Malwa Plateau Agro climatic zone of western Madhya Pradesh are low in soil available organic matter content, available nitrogen, available sulphur, low to medium in available phosphorus high in available potassium. Regarding available micronutrients, zinc, Manganese, copper and iron were deficient to sufficient in these soils. Soil organic carbon, available $\mathrm{N}, \mathrm{P}, \mathrm{Zn}, \mathrm{Mn}, \mathrm{Cu}$, and $\mathrm{Fe}$ are important soil fertility constraints indicating their immediate attention for sustained crop production. The deficient micronutrient may be replenished to avoid the crops suffering from their deficiency and for optimum utilization of other nutrients. Integrated nutrient management holds the key for sustainable soil fertility management. 


\section{Introduction}

Soil fertility refers to the inherent capacity of a soil to supply essential nutrients to plants in adequate amount, in correct proportion at right-time for their optimum growth. Fertilizers, therefore, assume a great significance and constitute one of the key inputs for achieving high productivity. Evaluation of soil fertility consists of estimating the nutrient-supplying power of a soil. A proper evaluation of the fertility of a soil before planting the crop helps in adopting appropriate measures to make up for the shortcomings and ensuring a good crop production. Optimum productivity of any cropping system depends on adequate supply of plant nutrients. Although one or more nutrients commonly applied to most crops, the quantity of nutrients removed in the harvested crop is generally much greater than the quantity added. Continued removals of nutrients by crop create specific nutrient deficiency in soil plant stress and yield loss.

When the soil does not supply sufficient nutrients for normal plant development and optimum productivity, application of supplemental nutrients is required. Soil testbased fertility management is an effective tool for increasing productivity of agricultural soils that have a high degree of spatial variability. However, major constraints impede wide scale adoption of soil testing in most developing countries. In India, these include the prevalence of small holding systems of farming as well as lack of infrastructural facilities for extensive soil testing. Under this context, the current study was carried out to assess the soil fertility evaluation with regard to soil testing in the Golpura village of Dhar district of western Madhya Pradesh. This study presents the soil spatial variability for soil texture, $\mathrm{pH}, \mathrm{EC}$, organic carbon, available $-\mathrm{N}, \mathrm{P}, \mathrm{K}, \mathrm{S}, \mathrm{Zn}, \mathrm{Cu}, \mathrm{Mn}$ and $\mathrm{Fe}$. The information generated will be useful for managing soil resources of the village on sustainable basis. By evaluating the soil fertility one can judicious use the fertilizer looking to the above performed statement it is imperative to find the soil fertility of specific area under a study is intensive cultivation. The study was planed with the following specific objectives: to determine the nutrient status $(\mathrm{N}$, $\mathrm{P}, \mathrm{K}$ and $\mathrm{S}$ ) of the soils of Golpura village, to estimate the micronutrient status $(\mathrm{Zn}, \mathrm{Cu}, \mathrm{Fe}$ and $\mathrm{Mn}$ ) of the soils of Golpura village to determine the textural class of sampled soils of the Golpura village and to assess the soil reaction $(\mathrm{pH})$ and electrical conductivity (EC) in different soil samples of the study area.

\section{Materials and Methods}

The village Golpura is about $35 \mathrm{~km}$, away from Dhar, which is surrounded by villages Baledi in South, Meda in North-west, Barkhedi in North-East side. The village is under the administration of - Gram Panchayat: Golpura, which comes under the block Sardarpur. This block is under the Dhar district of Madhya Pradesh state. This village comes under the western zone of Madhya Pradesh. The region generally experiences hot, sub-tropical climate, having average rainfall of $762 \mathrm{~mm}$, with erratic pattern of distribution, mostly concentrated in the month of June to September. 100 Soil samples $(0-15 \mathrm{~cm})$ at random were collected during May 2014 with help of Khurpi. Soil pH was determined in a 1: 2 soil: water suspension by glass electrode Beckman pH meter (Jackson, 1967). The soil suspension used for $\mathrm{pH}$ determination was allowed to settle down and conductivity of supernatant liquid was determined by using conductivity meter (Jackson, 1967). The results are expressed in $\mathrm{dSm}-1$ at 25oC. Organic carbon content in soil was determined by Walkley and Black's rapid titration method (1934). The value at end point was noted down from the burette and organic carbon content was estimated by using the formulae. 
O.C. $(\%)=\frac{\mathrm{X}-\mathrm{Y}}{2}$

Where,

$\mathrm{X}=$ Blank reading

$\mathrm{Y}=$ Titrated value

Available Nitrogen was determine by alkaline permanganate method (Subbiah and Asija, 1956). Available phosphorus was determined by using Olsen's extractant $(0.5 \mathrm{~N}$ sodium bicarbonate solution of $\mathrm{pH} 8.5$, Olsen et al., 1954). The amount of potassium present in extract was determined by flame photometer as described by Jackson (1967). The results were calculated as $\mathrm{K} \mathrm{kg} / \mathrm{ha}$. Available sulphur was determined the method given by Chesnin and Yien (1951). Weight $10 \mathrm{~g}$ of soil in 100 $\mathrm{ml}$ conical flask. Add $20 \mathrm{ml}$ of DTPA extractant and shake for 2 hrs on mechanical shaker. Filter the content through Whatman no. 42 filter paper, discarding first few drops. Keep the filterate to be analysed for $\mathrm{Zn}, \mathrm{Cu}$, $\mathrm{Mn}, \mathrm{Fe}$ with an atomic absorption spectrophotometer in polyethylene bottles. Also keep a blank with each set following all the step except the soil. Take suitable quantity of aliquot in a $100 \mathrm{ml}$ volumetric flask. Make up the volume to $100 \mathrm{ml}$ with glass disttiled water. Calibrate the AAS with the standard of the element to be analysed. Take reading of $\mathrm{Zn} / \mathrm{Fe} / \mathrm{Mn} / \mathrm{Cu}$ on ASS. $0.1 \mathrm{~m}$ triethanol amine buffered at $\mathrm{pH} 7.3$ (Lindsay and Norvell, 1978) and concentrations were analysed by atomic absorption spectrophotometer. The categorization of the soils of the individual blocks as a whole in to the three fertility classes was done according to the nutrient index values calculated from the soil test summaries giving their percentage distribution into low, medium and high categories.

The nutrient index (Muhr et al., 1965) was given by- Nutrient index $=[\%$ in high category $\times 3+\%$ in medium Category $\times 2+$ $\%$ in low category $\times 1] / 100$

In this percent assessment a nutrient index less than 1.65 denotes low category and that falling between 1.65 and 2.33 represents the medium fertility class. Value of 2.34 and above (maxi 3.00) signifies a high fertility class in respect of the particular nutrient (Ghosh and Hasan, 1976).

\section{Results and Discussion}

Considering the soil test rating for available $\mathrm{N}$ ( $<250$ as low, $250-400$ as medium and $>400$ as high in the status of $\mathrm{N}$ ) the soils of Golpura fall under low status $\left(<250 \mathrm{~kg} \mathrm{ha}{ }^{-1}\right)$ in available $\mathrm{N}$ content. In general out of 100 samples, 84 fall under low status and 16 samples were categorized under medium $\mathrm{N}$ status.

The general statistics calculated from 100 soil samples revealed that the available $\mathrm{N}$ content ranged from 145-263 $\mathrm{kg} \mathrm{ha}^{-1}$ (Table 1) with a mean value of $217.4 \mathrm{~kg} \mathrm{ha}{ }^{-1}$, standard deviation $33.766 \mathrm{~kg} \mathrm{ha}^{-1}$ and Coefficient of Variation (CV) $15.53 \%$.

The available $\mathrm{P}$ content (Table 2) of the soils of Golpura village ranged from 7.6 to $28.95 \mathrm{~kg}$ $\mathrm{ha}^{-1}$ with an average value of $19.64 \mathrm{~kg} \mathrm{ha}^{-1}$. Considering the soil test rating for available $\mathrm{P}$ $\left(<12.5 \mathrm{kgha}^{-1}\right.$ as low, $12.5-25.0 \mathrm{kgha}^{-1}$ as medium and $>25.0 \mathrm{kgha}^{-1}$ as high in the status of P) the soils of Golpura fall under low, medium and high status in available $\mathrm{P}$ content. In general out of 100 samples, 11 samples fall under low status, 69 samples under medium $\mathrm{P}$ status and 20 samples were high in $\mathrm{P}$ status. The general statistics calculated from 100 soil samples revealed that the available $-\mathrm{P}$ content ranged from 7.6 - $28.95 \mathrm{~kg} \mathrm{ha}^{-1}$ with a mean value of $19.64 \mathrm{~kg} \mathrm{ha}^{-1}$, standard deviation 6.23 $\mathrm{kgha}^{-1}$ and Coefficient of Variation (CV) $31.75 \%$. 
Table.1 Distribution of available nitrogen status in the soils of Golpura village

\begin{tabular}{|c|c|c|}
\hline Available $-\mathbf{N}\left(\mathrm{kg} \mathrm{ha}^{-1}\right)$ & No. of Samples & $\%$ Samples \\
\hline $\operatorname{Low}(<250)$ & 84 & 84 \\
\hline Medium(250-400) & 16 & 16 \\
\hline High $(>400)$ & NIL & \\
\hline \multicolumn{3}{|l|}{ General statistics: } \\
\hline Range $\left(\mathrm{kgha}^{-1}\right)$ & \multicolumn{2}{|c|}{$145-263$} \\
\hline Mean $\left(\mathrm{kgha}^{-1}\right)$ & \multicolumn{2}{|c|}{217.4} \\
\hline Standard deviation $\left(\mathrm{kgha}^{-1}\right)$ & \multicolumn{2}{|c|}{33.76} \\
\hline Coefficient of Variation (\%) & \multicolumn{2}{|c|}{15.53} \\
\hline
\end{tabular}

Table.2 Distribution of available phosphorus status in the soils of Golpura village

\begin{tabular}{|l|c|c|}
\hline A vailable-P $\left(\mathrm{kg} \mathrm{ha}^{-1}\right)$ & No. of Samples & \% Samples \\
\hline Low(<12.5) & 11 & 69 \\
\hline Medium (12.5-25) & 69 & 20 \\
\hline High (>25) & 20 & \\
\hline General statistics: & & $\mathbf{7 . 6 - 2 8 . 9 5}$ \\
\hline Range $\left(\mathrm{kgha}^{-1}\right)$ & $\mathbf{1 9 . 6 4}$ \\
\hline Mean $\left(\mathrm{kgha}^{-1}\right)$ & $\mathbf{6 . 2 3}$ \\
\hline Standard deviation $\left(\mathrm{kgha}^{-1}\right)$ & & \\
\hline Coefficient of variation $(\%)$ & & 31.75 \\
\hline
\end{tabular}

Table.3 Distribution of available potassium status in the soils of Golpura village

\begin{tabular}{|c|c|c|}
\hline Available-K (kg ha $\left.{ }^{-1}\right)$ & No. of Samples & $\%$ Samples \\
\hline Low $(<135)$ & - & - \\
\hline Medium (135-335) & 77 & 77 \\
\hline High (>335) & 23 & 23 \\
\hline \multicolumn{3}{|l|}{ General statistics: } \\
\hline Range $\left(\mathrm{kgha}^{-1}\right)$ & \multicolumn{2}{|l|}{ 215-391 } \\
\hline Mean $\left(\mathrm{kgha}^{-1}\right)$ & \multicolumn{2}{|l|}{298} \\
\hline Standard deviation $\left(\mathrm{kgha}^{-1}\right)$ & \multicolumn{2}{|l|}{126.88} \\
\hline Coefficient of variation (\%) & \multicolumn{2}{|l|}{42.6} \\
\hline
\end{tabular}


Table.4 Distribution of available sulphur status in the soils of Golpura village

\begin{tabular}{|l|c|l|l|}
\hline A vailable-S $\left(\mathrm{kg} \mathrm{ha}^{-1}\right)$ & No. of Samples & $\%$ Samples \\
\hline Low $(\mathbf{2 0})$ & 95 & & 95 \\
\hline Medium $(\mathbf{2 0}-\mathbf{4 0})$ & 5 & & 5 \\
\hline High $(>40)$ & NIL & & NIL \\
\hline General statistics: & & $7.25-21.5$ & \\
\hline Range $\left(\mathrm{kgha}^{-1}\right)$ & 12.93 & \\
\hline Mean (kgha-1) & & 0.20 & \\
\hline Standard deviation (kgha & & \\
\hline Coefficient of variation $(\%)$ & & 47.22 & \\
\hline
\end{tabular}

The variation in available $-\mathrm{P}$ is quite large which might be due to variation in soil properties viz., $\mathrm{pH}$, organic matter content, texture and various soil management and agronomic practices adopted by the farmers of the region.

The available $\mathrm{K}$ content (Table 3 ) of the soils of Golpura village ranged from 215 to $391 \mathrm{~kg}$ $\mathrm{ha}^{-1}$ with an average value of $298 \mathrm{~kg} \mathrm{ha}^{-1}$. Considering the soil test rating for available $\mathrm{K}$ (< $135 \mathrm{kgha}^{-1}$ as low, $135-335 \mathrm{kgha}^{-1}$ as medium and $>335 \mathrm{kgha}^{-1}$ as high in the status of $\mathrm{K}$ ) the soils of Golpura fall under medium and high status in available $\mathrm{K}$ content. In general out of 100 samples, 77 samples fall under medium status and $23 \%$ samples were high in $\mathrm{K}$ status. The general statistics calculated from 100 soil samples revealed that the available $-\mathrm{K}$ content ranged from 215 to $391 \mathrm{~kg} \mathrm{ha}^{-1}$ with a mean value of $297.85 \mathrm{~kg}$ $\mathrm{ha}^{-1}$, standard deviation $126.88 \mathrm{kgha}^{-1}$ and Coefficient of Variation (CV) $42.6 \%$.

\section{Available $\mathbf{S}$ status of the soils of Golpura village}

The available $\mathrm{S}$ content (Table 4 ) of the soils of Golpura village ranged from 7.25 to 21.5 $\mathrm{kg} \mathrm{ha}^{-1}$ with an average value of $12.93 \mathrm{~kg} \mathrm{ha}^{-1}$. Considering the soil test rating for available $\mathrm{S}$ (<20 kgha ${ }^{-1}$ as low, 20-40 $\mathrm{kgha}^{-1}$ as medium and $>40 \mathrm{kgha}^{-1}$ as high in the status of S) the soils of Golpura fall under low and medium status in available $S$ content. In general out of 100 samples, 95sample fall under low status and 5 samples were medium in $\mathrm{S}$ status. The general statistics calculated from 100 soil samples revealed that the available $S$ content ranged from 7.25 to $21.5 \mathrm{~kg} \mathrm{ha}^{-1}$ with a mean value of $12.93 \mathrm{~kg} \mathrm{ha}^{-1}$, standard deviation $0.20 \mathrm{~kg} \mathrm{ha}^{-1}$ and Coefficient of Variation (CV) $47.22 \%$.

The $\mathrm{pH}$ of soils of Golpura village ranges from 6.8-7.6 with a mean value of7.25, standard deviation 0.25 and coefficient of variation $3.4 \%$. Electrical Conductivity of soil ranges from $0.19-0.86 \mathrm{dsm}^{-1}$ with a mean value of $0.36 \mathrm{dsm}^{-1}$ Standard deviation 0.13 and CV 3.4. The available organic carbon content of the soils of Golpura village ranged from $0.31-0.70 \%$ with an average value of $0.55 \%$. The available $\mathrm{Zn}$ content of the soils of Golpura village ranged from $0.22-1.18$ $\mathrm{mgkg}^{-1}$ with an average value of $0.58 \mathrm{mgkg}^{-1}$. The available $\mathrm{Fe}$ content of the soils of Golpura village ranged from $3.29-10.37$ 
$\mathrm{mgkg}^{-1}$ with an average value of $6.0 \mathrm{mgkg}^{-1}$. The available Mn content of the soils of Golpura village ranged from $1.68-4.42 \mathrm{mgkg}^{-1}$ with an average value of $2.87 \mathrm{mgkg}^{-1}$. The available $\mathrm{Cu}$ content of the soils of Golpura village ranged from $0.08-0.84 \mathrm{mgkg}^{-1}$ with an average value of $0.38 \mathrm{mgkg}^{-1}$. Soil textural analysis was carried out by Bouyoucos Hydrometer method to determine the relative percentage of sand silt and clay in 100 surface soil samples collected from village Golpura.

In Golpura village soils, $\mathrm{pH}$ ranged from neutral to strightly alkaline. Similar observations were made by singh et al., (2009) in surface and subsurface soils of district Gajipur Uttar Pradesh. Higher $\mathrm{pH}$ values were also recorded by Balpande et al., (1996) in degraded Vertisols in Purnavalley. $\mathrm{pH}$ increased with depth. The soil surface to lower Electrical conductivity was safe range in Golpura village. Similar types of results are reported by Bali et al., (2010) and Ved et al., (2008) in soils of Panjab and U.P states. Organic carbon content of Golpura soils ranged from 0.31 to 0.70 percent respectively, which in general accumulated in surface layers. Observations in the line with the present findings have been reported in Nazif et al., (2006). Similar findings were reported by Lathwal (2006) in district Kurukshetra, Haryana and Sharma et al., (2008) in soils of Amritsar District. Similar results were also noted by Sharma et al., (2008) in soil of Amritsar district and Lathwal (2006) in soil of Shahbad and Thaneshwar block. An average value of $\mathrm{OC}$ of the soil was found minimum i.e. $0.31 \%$, in the village and maximum i.e. $0.70 \%$ in village (Appendix II) of Golpura village. The available nitrogen content varied between 145 to $263 \mathrm{~kg}$ per ha. Available phosphorus ranged from 7.6 to $28.95 \mathrm{~kg}$ per ha. Available potassium ranged from 215 to $391 \mathrm{~kg}$ per ha, respectively. Rajeshwar et al., (2009), Kumar et al., (2009) and Sharma a et al., (2008), observed a similar trend of nutrient status in study area soils. The medium nitrogen status was noticed in some area may be due to application of $\mathrm{N}$ fertilizer coupled with high vegetative cover. Kumar et al., (2009) in Dumka and Lachimpur series, Ashok et al., (2006) in Auraiya district of Uttar Pradesh observed a similar trend of nutrient status in study area soils. The available phosphorus content was medium (69\% samples) in major parts of the village, but it was low (11\% samples) in the soil of Golpura village. The present findings are in line with those of Mostara (2002) who reported that majority of soils in Karnataka and more so in Malprabha command were medium in phosphorus content. Nirawar et al., (2009) and Kumar et al., (2009) in Dumka and Lachimpur series of Jharkhand were medium in phosphorus content. The available potassium content in major portion of the study area was under medium to high category of the village. Similar results were observed by Verma et al., (2005) in soils of Sardulgarh, Bhikhi and Budhlada blocksand Nirawar et al., (2009) in soils of Ahemedpur tahsil of Latur district. The area under medium and low category for sulphur was found In general out of 100 samples, $95 \%$ fall under low status and $5 \%$ samples were categorized under medium $\mathrm{S}$ status. Similar results were also reported by Chouhan et al., (2012) in the soils of dewas District in Madhya Pradesh and Singh et al., (1993) in garhwal region of western Himalayas. In Golpura soils the available zinc was to be deficient in the entire study are except in about $61 \%$ samples of the village was deficient.

The results are in conformity with the finding of Sharma and Chaudhari (2007) in soils of Solan district in North-West Himalayas and also similar findings by Rajeswar et al., (2009). Golpura village soils fall under deficient $6 \%$ of entire study area of the village and sufficient category $93 \%$ from the $\mathrm{Fe}$ 
status. The available iron in surface soils has no regular pattern of distribution as reported by Nayak et al., (2002). Major portion of the study area $54 \%$ out of 100 sample of the village was under sufficient rating for available copper status and some area was under deficient for available copper (5\%) Singh et al., (2014) reported that available copper content in Madhya Pradesh soils ranged from 0.08 to $1.18 \mathrm{ppm}$. Similar results were also observed by Singh and Raj (1996) in flood plains of Himachal Pradesh. In Golpura village soil samples the available manganese was found to be deficient in almost $89 \%$ of the village of study area and sufficient in remaining fields. Similar findings were also reported by Singh et al., (2009) in the soils of District Ghazipur, Uttar Pradesh. Soil $\mathrm{pH}$ showed positive correlation with available - $\mathrm{k}(\mathrm{r}=0.059), \quad \mathrm{P}(\mathrm{r}=0.213)$ and $\mathrm{S}(\mathrm{r}=0.264)$, while it showed negative correlation with available $\mathrm{N}(-0.113)$, EC $(-0.189)$, OC $(-0.087)$ and $\mathrm{Zn}(\mathrm{r}=-0.288)$. Similar findings were also reported by Sharma et al.,(2008), Waghmare et al., (2009) Ghosh et al.,(2006) and Meena et al.,(2006)in soils of Amritsar district, Latur district, North Bengal and Rajasthan and Similar findings were also reported by Sood et al., (1995) in soils of Malwa plateau Rajasthan, Jena et al., (2008) in soils of Orrisa, Meena et al., (2006) in soils of Tonk district of Rajasthan, Najif et al., (2006) in soils of district Bhimber, Kumar et al.,(2009) in soils of Jharkhand and Sahoo et al.,(1995) in soils of Rajasthan. Electrical conductivity of these soils showed positive correlation with, available $\mathrm{OC}(\mathrm{r}=0.081)$, $\mathrm{Zn}(\mathrm{r}=0.247), \mathrm{Fe}(\mathrm{r}=0.131), \mathrm{N}(\mathrm{r}=0.078)$ and $\mathrm{S}(\mathrm{r}=0.011)$ and negative correlation with available $\mathrm{P}(\mathrm{r}=-0.256), \mathrm{K}(\mathrm{r}=-0.086)$, in soils of Golpura village. Similar results were also reported by Sharma and Chaudhary (2007) in lower Shiwaliks of Solan district in NorthWest Himalayas. Maji et al., (1993) in coastal soils of Sunderbans, West Bangal. Data of organic carbon showed positive correlation with available $\mathrm{N}(\mathrm{r}=0.993), \quad \mathrm{P}(\mathrm{r}=0.089)$, $\mathrm{K}(\mathrm{r}=0.090)$, and $\mathrm{Zn}(\mathrm{r}=0.221)$ and negative correlation with $\mathrm{S}(\mathrm{r}=-0.065)$, in study area soils. Similar findings were also reported by Sharma et al., (2008), Meena et al., (2006) and Kumar et al., (2009) in soils of Amritsar district, Rajasthan and Jharkhan.

From the study, it can be concluded that, soils of Golpura village in Malwa Plateau Agro climatic zone of western Madhya Pradesh are low in soil available organic matter content, available nitrogen, available sulphur, low to medium in available phosphorus high in available potassium. Regarding available micronutrients, zinc, Manganese, copper and iron were deficient to sufficient in these soils. Soil organic carbon, available N, P, Zn, Mn, $\mathrm{Cu}$, and $\mathrm{Fe}$ are important soil fertility constraints indicating their immediate attention for sustained crop production. The deficient micronutrient may be replenished to avoid the crops suffering from their deficiency and for optimum utilization of other nutrients. Integrated nutrient management holds the key for sustainable soil fertility management.

\section{References}

Ashok. G. Singh R, Aggarwal S. and Kumar P. (2006). NPK status of wheat growing soils in Auraiya district of Uttar Pradesh. International J.Agric. Sci. 2006; 2(1): 286-287.

Bali, S. K., R. Kumar, H.S. Hundal, K. Singh and Singh B. (2010). GIS- aided Mapping of DTPA- Extractable Zinc and soil characteristics in the status of Punjab. J. Indian Soc. Soil Sci. 58(2): 189-199.

Chesnin and Yein (1951) Turbiditimetric determination of available sulphur. Soil Science Society of America proceedings. 35, 658-659. 
Chouhan, N.; Sharma, G.D.; Khamparia, R.S.; Sahu R.K (2012). Status of sulphur and micronutrients in medium black soils of Dewas district, Madhya Pradesh. Agropedology; 22(1):66-68. 8 ref.

Ghosh, A. B. and Hussan, R. (1976).Available potassium status of Indian soil. Bull. Indian Soc. of Soil Sci.12: 1-18.

Kumar, R., Sarkar, A. S., Singh, K. P., Agarwal, B. K. and Karmakar, S. (2009). Appraisal of available nutrients status in Santhal Paraganas region of Jharkhand.J. Indian Soc. Soil Sci. 57(3): 366-369.

Lathwal, O. P. (2006). Soil fertility status of district Kurukshetra (Haryana). Haryana J. Agron. 22(1): 74-76.

Maji, B., Chatterji, S. and Bandyopadhya, B. K. (1993). Available iron, manganese, zinc and copper in coastal soils of Sundarbans, West Bengal in relation to soil characteristics. J. Indian Soc. Soil Sci. 41 (3): 468-471.

Meena, H. B., Sharma, R. P. and Rawat, U. S. (2006). Status of Macro and Micronutrients in some soils of Tonk District of Rajasthan. J. Indian Soc. Soil Sci. 54(4): $508-512$.

Mostara, M.R. (2002). Rock phosphate as a fertilizer for direct application in acid soils. J. Ind. Soil Sci., 19: 107-113.

Muhr, G. R., Datta, N. P., Sankara Subramoney, N., Dever, F., Lecy, V. K. and Donahue, R.R. (1965). Soil testing in India. USAID. Mission to India, New Delhi.

Nayak, R.K.; Sahu, G.C. and Nanda, S.S.K. (2002). Characterization and Classification of the Soil of Central Station, Research. Bhubaneswar Agropedology, 12:1-8.

Nazif, W. Perveen, S. and Saleem, I. (2006). Status of micronutrients in soils of district Bhimber (Azad Jammu and Kashmir). J. Agric. \& Biological Sci. 1(2): 35-40

Nazif, W. Perveen, S. and Saleem, I. (2006). Status of micronutrients in soils of district Bhimber (Azad Jammu and Kashmir). J. Agric. \& Biological Sci. 1(2): 35-40

Nirawar, G. V., Mali C.V. and Waghmare M.S. (2009). Physico chemical characteristics and status of available $\mathrm{N}, \mathrm{P}$ and $\mathrm{K}$ in soils from Ahemedpur tahsil of Latur district. An Asian J. Soil Sci. 4(1): 130-134.

Rajeswar, M., Rao C.S., Balaguravaiah D. and Khan M.A.A. (2009). Distribution of Available Macro and Micronutrients in Soils Garikapadu of Krishna District of Andhra Pradesh. J. Indian Soc. Soil Sci. 57(2): 210-213.

Sharma, J. C. and Chaudhary, S. K. (2007). Vertical distribution of micronutrient cations in relation to soil characteristics in lower Shiwaliks of Solan District in North - West Himalayas J. Indian Soc. Soil Sci. 55(1): 40-44.

Sharma, P. K., Sood, A., Setia, R. K., Tur, N. S., Mehra, D. and Singh, H. 2008. Mapping of macronutrients in soils of Amritsar district (Punjab) A GIS approach. J. Indian Soc. Soil Sci. 56 (1): 34-41.

Singh, S. P., Singh, R., Srivastava, P. C. and Singh, P. (2009). Different forms of sulphur in soils of Udham Singh Nagar district, Uttarakhand and their relationship with soil properties. Agropedology 19(1): 68-74.

Singh, Y.P., Raghubanshi, B.P.S.,.Tomar, R. S., Verma, S.K. and, Dubey, S.K. (2014) Soil Fertility Status and Correlation of Available Macro and Micro nutrients in Chambal region of Madhya Pradesh,. J. Indian soc. soil sci. 62(4); 369-375.

Sinhg, K., Pratap Narain, Sharda, U.N. and Juyal, G.P. (1993). Soil characteristics 
under different land use in Fakat watershed of western Himalayas (UP). Indian J. Soil Conser. 21(3):14-24

Sood, A. K., Chattopadhayay T., Singh R. S. and Shysmpura R. L. (1995). Available micronutrient status in the soils of Malwa platue Rajasthan. $J$. Indian Soc. Soil Sci. 43(4): 698-700.

Verma, V. K., Setia R. K., Sharma P.K., Singh C. and Kumar A. (2005). Pedospheric variations in distribution of DTPA-extractable micronutrients in soils developed on different physiographic units in central parts of Punjab, India. International J. Agric. and Biology 7: 243-246.

Waghmare, M. S.; Bavalgare, V. G.; Deshmukh, V. A. and Takankhar, V. G. (2009). Status of available N, P and K in some soil of Ausa tahsil of Latur district. International J. Trop. Agric. 27(1-2): 327-331.

\section{How to cite this article:}

Chandan Bala Lohiya, Shila P.K. Unni and Sanjay Sharma. 2018. Evaluation of Soil Fertility of Golpura Village of Dhar District of Western Madhya Pradesh, India. Int.J.Curr.Microbiol.App.Sci. 7(04): 221-229. doi: https://doi.org/10.20546/ijcmas.2018.704.024 